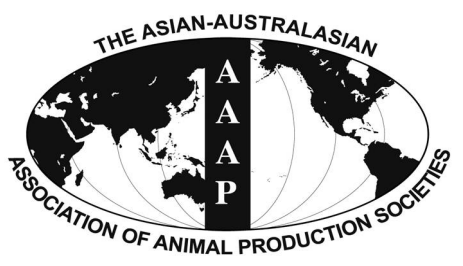

Open Access

Asian Australas. J. Anim. Sci.

Vol. 28, No. 9 : 1274-1280 September 2015

http://dx.doi.org/10.5713/ajas.15.0106

Www.ajas.info

pISSN 1011-2367 elSSN 1976-5517

\title{
Effect of Microbial and Chemical Combo Additives on Nutritive Value and Fermentation Characteristic of Whole Crop Barley Silage
}

\author{
Dong Hyeon Kim ${ }^{1, a}$, Sardar M. Amanullah ${ }^{1,2, a}$, Hyuk Jun Lee ${ }^{1}$, Young Ho Joo ${ }^{1}$, and Sam Churl Kim ${ }^{1, *}$ \\ ${ }^{1}$ Division of Applied Life Science (BK21 Plus \& Institute of Agriculture and Life Science), \\ Gyeongsang National University, Jinju 660-701, Korea
}

\begin{abstract}
This study was conducted to assess the effects of microbial and chemical combo additives on nutritive values, fermentation indices and aerobic stability of whole crop barley silage. Barley forage (Youngyang) was harvested at about $30 \%$ dry matter (DM) by treatments, chopped to $5 \mathrm{~cm}$ length and treated with distilled water only (CON), Lactobacillus plantarum (INO), propionic acid (PRO) or an equal mixture of INO and PRO (MIX). Barley forages were ensiled in 4 replications for 0, 2, 7, and 100 days. On 100 days of ensiling, MIX silage had higher $(\mathrm{p}<0.05)$ in vitro DM digestibility than CON silage, but lower $(\mathrm{p}<0.05)$ acid detergent fiber concentration. The $\mathrm{pH}$ in all treated silages was lower $(\mathrm{p}<0.05)$ than CON silage. The MIX silage had higher $(\mathrm{p}<0.05)$ lactate concentration and lactate to acetate ratio than in CON, but lower $(\mathrm{p}<0.05)$ yeast count. Aerobic stability in CON, PRO, and MIX silages were higher $(\mathrm{p}<0.05)$ than in INO silage. It is concluded that microbial and chemical combo additives using $L$. plantarum and propionic acid could efficiently improve nutritive values of barley silage in terms of increased in vitro DM digestibility compared to other treatments. In addition, all treatments except CON reduced yeast count which is the initiate microorganism of aerobic spoilage. (Key Words: Aerobic Stability, Barley Silage, Fermentation Indices, Lactobacillus Plantarum, Propionic Acid)
\end{abstract}

\section{INTRODUCTION}

In forage ensiling process, emphasis is given to a high degree of lactic acid production followed by rapid reduction of $\mathrm{pH}$ for effective preservation of ensiled forage material (Cleale et al., 1990; Bolsen et al., 1996). To ensure vigorous production of lactic acid, often homofermentative lactic acid bacteria (LAB) like Lactobacillus plantarum are used as silage additive (Muck, 2004; Sucu and Filya, 2006). Study suggests that these LAB inoculants are efficient at improving silage fermentation indices (Weinberg and Muck, 1996), but lack of consistency also reported (Muck, 1993). Furthermore, silages treated with homofermentative inoculants are more prone to aerobic spoilage after silo

\footnotetext{
* Corresponding Author: Sam Churl Kim. Tel: +82-55-772-1947, Fax: +82-55-772-1949, E-mail: kimsc@gnu.ac.kr

2 Bangladesh Livestock Research Institute, Dhaka 1314, Bangladesh.

${ }^{a}$ The first two authors contributed equally to this study.

Submitted Feb. 8, 2015; Revised Mar. 30, 2015; Accepted Apr. 29, 2015
}

opening (Muck and Kung, 1997). Use of homofermentative inoculants result in a relatively greater level of residual water soluble carbohydrates (WSC) and lactate in silage, which in the presence of oxygen are used as substrate by spoilage-causing yeasts and molds (Weinberg and Muck, 1996). As a result, the $\mathrm{pH}$ rises and other micro-organisms start to grow (Lindgren et al., 1985), which results in losses of nutritional value (Woolford, 1984; Courtin and Spoelstra, 1990).

To reduce this sort of aerobic spoilage and nutrient losses, microbial and chemical additives were suggested earlier. Among microbial additives, heterofermentative $L$. buchneri inoculants (Muck, 1996; Ranjit and Kung, 2000; Dreihuis et al., 2001) or propionic acid forming bacteria (Higginbotham et al., 1998; Filya and Sucu, 2007) can inhibit the growth of yeasts and mold. Chemical additives, such as propionic acid (Kung et al., 1998; Kung et al., 2000; Mills and Kung, 2002), can act as agents to inhibit yeast and mold growth and thus improves aerobic stability. Using a simulation model of silage fermentation and aerobic 
stability, Pitt et al. (1991) concluded that propionic acid is more effective improving aerobic stability than microbial inoculation. Woolford (1975) stated that propionic acid has the greatest anti-mycotic activity among the short chain fatty acids. However, the combined use of a homolactic bacterial inoculant and an efficient inhibitor of aerobic spoilage organism may help rapid reduction of $\mathrm{pH}$ at an early stage as well as increases of aerobic stability at silo opening. The combined effect of $L$. plantarum and propionic acid on barley silage was not tested earlier. Moreover, as barley forage contains high level of fermentable carbohydrates (Hargreaves et al., 2009), additional use of inoculants may ensure efficient fermentation to produce good quality silage. Therefore, this study was conducted to determine the effects of pure propionic acid, inoculation of $L$. plantarum and the equal mixture of these two on chemical composition, fermentation characteristics and aerobic stability of whole crop barley silage.

\section{MATERIALS AND METHODS}

\section{Preparation of silage}

Barley forage (Youngyang hybrid) was grown in the Animal Research Farm, Gyeongsang National University (Jinju, Korea) and harvested at dough stage when the forage dry matter (DM) level was about $30 \%$. About $260 \mathrm{~kg}$ of forage was harvested, chopped to $5 \mathrm{~cm}$ length and divided into equal four piles $(65 \mathrm{~kg}$ in each). These forage piles were treated with i) distilled water only ( $\mathrm{CON}$, distilled water at $2 \mathrm{~mL} / \mathrm{kg}$ of fresh forage); ii) Chungmi-Lacto (INO, L. plantarum at $1.5 \times 10^{7} \mathrm{cfu} / \mathrm{g}$ of fresh forage, CMbio, Anseong, Korea); iii) propionic acid (PRO, $13.5 \mathrm{M}$ propionic acid at $1 \mathrm{~g} / \mathrm{kg}$ of fresh forage, Yakuri, Osaka, Japan); and iv) a mixture of 2 and 3 with 1 to 1 of ratio (MIX, mixture at $2 \mathrm{~mL} / \mathrm{kg}$ of fresh forage), separately. Measured amounts of inoculant and/or propionic acid were dissolved in $130 \mathrm{~mL}$ of distilled water to spray over forages so that the additional moisture would be equal in all treatments. Then the treated forages were ensiled in four replications (each containing $4 \mathrm{~kg}$ of forage) in mini-bucket silos for 100 days. Forage was compressed manually to remove air from the silo, sealed airtight and kept in dark place at room temperature. Similarly, $3 \mathrm{~kg}$ forages from each treatment were also ensiled in four replications for 2 and 7 days to observe the trend of silage fermentation at early stages of ensiling.

\section{Sampling and laboratory analysis}

At the day of silage making, a representative sample of untreated fresh forage was collected and preserved at $-20^{\circ} \mathrm{C}$ until analysis. The fresh forage samples were analyzed for chemical composition, neutral detergent fiber (NDF), acid detergent fiber (ADF), and hemicelluloses. In addition to these, the 100 day silage was also analyzed for in vitro DM digestibility (IVDMD), fermentation characteristics, microbial colony counts (LAB, yeast and mold) and polymerase chain reaction (PCR) analysis for L. plantarum DNA. Silage samples from days 2 and 7 were collected to determine the fermentation characteristics during these periods of ensiling.

At the day of each silo opening, $20 \mathrm{~g}$ of fresh silage was mixed with $200 \mathrm{~mL}$ of sterile ultra-pure water and macerated in a laboratory blender for 30 seconds to produce aqueous extract of silage (Adesogan et al., 2004). A part of this extract was used to determine $\mathrm{pH}$ and microbial colony counting (LAB, yeast and mold) at the day of silo opening and the rest was stored at $-20^{\circ} \mathrm{C}$ for the analyses of $\mathrm{NH}_{3}-\mathrm{N}$, lactate and volatile fatty acid (VFA), and the extraction of microbial DNA. About $500 \mathrm{~g}$ of fresh forage and 100 day silage were dried at $60^{\circ} \mathrm{C}$ for 48 hours and ground by a Wiley mill (Shinmyung Electric Co., Ltd., Gimpo, Korea) with $1 \mathrm{~mm}$ screen to use for chemical analysis.

To determine the DM content in fresh forage and silage, about $10 \mathrm{~g}$ of sample was placed in a hot air oven (OF$22 \mathrm{GW}$, JEIO TECH, Seoul, Korea) at $105^{\circ} \mathrm{C}$ for 24 hours. Organic matter $(\mathrm{OM})$ was determined by placing samples in a muffle furnace set at $550^{\circ} \mathrm{C}$ for 5 hours. Crude protein (CP) was determined following the standard Kjeldahl procedure and ether extract (EE) was determined by using Soxhlet apparatus (AOAC, 1995). NDF and ADF were determined by using Ankom ${ }^{200}$ fiber analyzer (Ankom Technology, Macedon, NY, USA) following the method of Van Soest et al. (1991). Amylase and sodium sulfite were used in the analysis of NDF. The IVDMD was determined following the method of Tilley and Terry (1963) using Ankom Daisy Incubator (Ankom Technology, USA). Silage $\mathrm{pH}$ was determined from aqueous extract of silage using a pH meter (SevenEasy, Mettler Toledo, Greifensee, Switzerland). The $\mathrm{NH}_{3}-\mathrm{N}$ was also determined from silage extract following the method of Chaney and Marbach (1962). To determine lactic acid and VFA, about $1.5 \mathrm{~mL}$ of silage extract was centrifuged at $5,645 \times \mathrm{g}$ for 15 minutes and then, supernatant was collected. Concentrations of lactate and VFA was measured in HPLC (L-2200, Hitachi, Tokyo, Japan) fitted with a UV detector (L-2400, Hitachi, Japan) and a column (Metacarb 87H, Varian, Palo Alto, CA, USA) according to the method described by Adesogan et al. (2004).

\section{Aerobic stability and microbial enumeration}

Aerobic stability was determined following Amanullah et al. (2014). Temperature was recorded by thermocouple wires placed into the center of the silage and connected to a computer assisted data logger (GTR-60CH MORGAN, Gilwoo Co., Seoul, Korea). Enumeration of LAB, yeast and 
mold were conducted by pour plating method. Lactobacilli MRS agar media (Difco, Detroit, MI, USA) was used for isolation and enumeration of LAB. On the other hand, potato dextrose agar (PDA, Difco, USA) was used for yeasts and molds. Ten-fold serial dilutions were made from fresh aqueous silage extract considering it as the first dilution. One hundred micro-liter $(100 \mu \mathrm{L})$ aliquots of three consecutive dilutions $\left(10^{-5}\right.$ to $\left.10^{-7}\right)$ were plated in triplicate onto the selective agar media described above. Lactobacilli MRS agar plates were placed in a $\mathrm{CO}_{2}$ incubator (Thermo Scientific, Waltham, MA, USA) at $39^{\circ} \mathrm{C}$ for $24 \mathrm{~h}$ and PDA plates were incubated at $39^{\circ} \mathrm{C}$ for $24 \mathrm{~h}$ in normal incubator (Johnsam Corporation, Seoul, Korea). Visible colonies were counted from the plates at appropriate dilutions and the number of colony forming units (CFU) was expressed per gram of silage.

\section{DNA extraction, primer and polymerase chain reaction condition}

The DNA of L. plantarum was extracted from silage extract using a QIAamp DNA mini kit (Qiagen, Valencia, CA, USA) following the manufacturer's protocol and the concentration of DNA was measured using a NanoDrop Spectrophotometer (ND-1000, Thermo Scientific, USA). Amplification of DNA was performed using Bio-Rad C1000 Touch Thermal cycler real-time PCR detection system (CFX96 Real-Time system, Bio-Rad Laboratories, Inc., Hercules, CA, USA). The primers used and PCR conditions followed were as described by Amanullah et al. (2014). The amplified fragments from PCR were subjected to electrophoresis on $1.5 \%$ agarose gel and visualized after staining with ethidium bromide under UV illumination.

\section{Statistical analysis}

The experiment was a completely randomized design. The data were analyzed using GLM procedure of SAS (2002). The model was $Y_{i j}=\mu+T_{i}+e_{i j}$, where $Y_{i j}=$ response variable, $\mu=$ overall mean, $\mathrm{T}=$ effect of treatment $\mathrm{i}$, and $e_{i j}$ $=$ error effect. Tukey test was performed to differentiate means. The significance was declared at $\mathrm{p} \leq 0.05$ level.

\section{RESULTS}

Chemical compositions of fresh barely forage before ensiling are described in Table 1. At early stages (2 and 7 days) of ensiling the $\mathrm{pH}$ of silage reduced $(\mathrm{p}<0.05)$ faster in INO compared to $\mathrm{CON}$; whereas $\mathrm{NH}_{3}-\mathrm{N}$ concentration was similar among three silages (Table 2). The PRO silages had higher $(\mathrm{p}<0.05)$ lactate concentration after 2 days of ensiling. Propionic acid concentration was numerically higher in PRO and MIX silages at early stages of ensiling.

Table 3 contains the chemical composition and DM digestibility of barley silage ensiled for 100 days. The DM,
Table 1. Chemical composition of barley forage (Youngyang) before ensiling ( $\%$ of dry matter)

\begin{tabular}{lc}
\hline Composition & Barley forage \\
\hline Dry matter & 29.7 \\
Organic matter & 91.87 \\
Crude protein & 7.84 \\
Ether extract & 2.82 \\
Neutral detergent fiber & 54.3 \\
Acid detergent fiber & 32.2 \\
Hemicellulose & 22.0 \\
\hline
\end{tabular}

NDF, and hemicelluloses were not affected by treatments $(p>0.05)$. CP concentration was decreased in INO silage, while EE was decreased in PRO silage compared to other treatments $(p<0.05)$. The OM content was higher $(p<0.05)$ in all treatments compared to the CON silage. ADF was higher in CON silage than that in other silages $(p<0.05)$.

The IVDMD was highest in MIX silage, followed by PRO, INO and CON silage $(\mathrm{p}<0.05)$.

The fermentation indices, aerobic stability and microbial counts in barley silage of 100 days are illustrated in Table 4 . The $\mathrm{pH}$ was significantly reduced $(\mathrm{p}<0.05)$ in all treated silages compared to the CON silage, however, there was no difference $(\mathrm{p}>0.05)$ in $\mathrm{pH}$ among the treated silages (INO, PRO, and MIX). The $\mathrm{NH}_{3}-\mathrm{N}$ (\% of DM) concentration was reduced significantly $(p<0.05)$ in PRO and MIX silages compared to $\mathrm{CON}$ and INO silages. However, when $\mathrm{NH}_{3}-\mathrm{N}$ concentration was expressed as percent of total nitrogen, the highest $\mathrm{NH}_{3}-\mathrm{N}$ was observed in INO, followed by CON, MIX, and PRO silages $(\mathrm{p}<0.05)$. The acetate concentration was lowest $(p<0.05)$ in INO

Table 2. Fermentation indices and microbial growth of barley silage (Youngyang) ensiled for 2 and 7 days (\% of dry matter or as stated)

\begin{tabular}{|c|c|c|c|c|c|}
\hline \multirow{2}{*}{ Variable } & \multicolumn{4}{|c|}{ Treatment } & \multirow{2}{*}{ SEM } \\
\hline & $\mathrm{CON}$ & INO & PRO & MIX & \\
\hline \multicolumn{6}{|l|}{2 Days } \\
\hline $\mathrm{pH}$ & $5.98^{\mathrm{a}}$ & $5.63^{\mathrm{b}}$ & $5.82^{\mathrm{ab}}$ & $5.97^{\mathrm{a}}$ & 0.149 \\
\hline $\mathrm{NH}_{3}-\mathrm{N}$ & 0.020 & 0.021 & 0.021 & 0.019 & 0.009 \\
\hline Lactate & $1.44^{\mathrm{b}}$ & $1.79^{\mathrm{b}}$ & $5.19^{\mathrm{a}}$ & $2.32^{\mathrm{b}}$ & 1.004 \\
\hline Acetate & 2.97 & 2.23 & 7.65 & 8.06 & 3.601 \\
\hline Propionate & 0.07 & 0.11 & 0.21 & 0.23 & 0.053 \\
\hline \multicolumn{6}{|l|}{7 Days } \\
\hline $\mathrm{pH}$ & $5.71^{\mathrm{a}}$ & $4.98^{\mathrm{b}}$ & $5.29^{\mathrm{ab}}$ & $5.39^{\mathrm{ab}}$ & 0.081 \\
\hline $\mathrm{NH}_{3}-\mathrm{N}$ & $0.074^{\mathrm{a}}$ & $0.064^{\mathrm{a}}$ & $0.056^{\mathrm{ab}}$ & $0.042^{\mathrm{b}}$ & 0.008 \\
\hline Lactate & $1.21^{\mathrm{b}}$ & $2.35^{\mathrm{ab}}$ & $3.48^{\mathrm{a}}$ & $3.47^{\mathrm{a}}$ & 0.764 \\
\hline Acetate & 1.37 & 0.89 & 1.19 & 1.55 & 0.524 \\
\hline Propionate & 0.05 & 0.05 & 0.14 & 0.13 & 0.041 \\
\hline
\end{tabular}

SEM, standard error of the mean.

$\mathrm{CON}$, distilled water at $2 \mathrm{~mL} / \mathrm{kg}$ of forage; INO, Lactobacillus. plantarum at $1.5 \times 10^{7} \mathrm{cfu} / \mathrm{g}$ of fresh forage; PRO, propionic acid at $1 \mathrm{~g} / \mathrm{kg}$ of forage; MIX, mixture of INO and PRO at 1:1 ratio.

a,b Means in the same row with different superscripts differ significantly $(\mathrm{p}<0.05)$. 
Table 3. Chemical composition of barley silage (Youngyang) ensiled for $100 \mathrm{~d}$ ( $\%$ of dry matter)

\begin{tabular}{|c|c|c|c|c|c|}
\hline \multirow{2}{*}{ Variable } & \multicolumn{4}{|c|}{ Treatment } & \multirow{2}{*}{ SEM } \\
\hline & $\mathrm{CON}$ & INO & PRO & MIX & \\
\hline Dry matter & 24.1 & 23.7 & 23.6 & 25.2 & 1.103 \\
\hline Organic matter & $91.09^{\mathrm{b}}$ & $91.97^{\mathrm{a}}$ & $92.48^{\mathrm{a}}$ & $92.25^{\mathrm{a}}$ & 0.366 \\
\hline Crude protein & $9.20^{\mathrm{a}}$ & $8.70^{\mathrm{b}}$ & $9.13^{\mathrm{a}}$ & $9.42^{\mathrm{a}}$ & 0.137 \\
\hline Ether extract & $4.14^{\mathrm{a}}$ & $4.21^{\mathrm{a}}$ & $3.57^{\mathrm{b}}$ & $4.04^{\mathrm{a}}$ & 0.127 \\
\hline Neutral detergent fiber & 58.30 & 54.47 & 54.98 & 54.87 & 1.669 \\
\hline Acid detergent fiber & $39.4^{\mathrm{a}}$ & $35.1^{\mathrm{b}}$ & $35.9^{\mathrm{b}}$ & $32.7^{\mathrm{b}}$ & 1.232 \\
\hline Hemicellulose & 19.8 & 19.9 & 19.6 & 18.9 & 0.986 \\
\hline In vitro dry matter digestibility & $42.6^{\mathrm{d}}$ & $44.3^{\mathrm{c}}$ & $47.1^{\mathrm{b}}$ & $50.3^{\mathrm{a}}$ & 0.595 \\
\hline
\end{tabular}

SEM, standard error of the mean.

CON, distilled water at $2 \mathrm{~mL} / \mathrm{kg}$ of forage; INO, Lactobacillus plantarum at $1.5 \times 10^{7} \mathrm{cfu} / \mathrm{g}$ of fresh forage; PRO, propionic acid at $1 \mathrm{~g} / \mathrm{kg}$ of forage; MIX, mixture of INO and PRO at 1:1 ratio.

${ }^{a, b}$ Means in the same row with different superscripts differ significantly $(p<0.05)$.

Table 4. Fermentation indices, aerobic stability and microbial growth of barley silage (Youngyang) ensiled for $100 \mathrm{~d}$ ( $\%$ of dry matter or as stated)

\begin{tabular}{lccccc}
\hline & \multicolumn{3}{c}{ Treatment } & & MIX \\
\cline { 2 - 5 } & CON & INO & PRO & $4.46^{\mathrm{b}}$ & 0.054 \\
$\mathrm{nyH}$ & $4.65^{\mathrm{a}}$ & $4.45^{\mathrm{b}}$ & $4.44^{\mathrm{b}}$ & $0.08^{\mathrm{b}}$ & 0.095 \\
$\mathrm{NH}_{3}-\mathrm{N}$ & $0.12^{\mathrm{a}}$ & $0.11^{\mathrm{a}}$ & $0.08^{\mathrm{b}}$ & $5.75^{\mathrm{c}}$ & 0.138 \\
$\mathrm{NH}_{3} \mathrm{~N}$ (\% of total N) & $6.45^{\mathrm{b}}$ & $8.31^{\mathrm{a}}$ & $5.10^{\mathrm{d}}$ & $6.21^{\mathrm{a}}$ & 0.328 \\
Lactate & $3.61^{\mathrm{b}}$ & $3.15^{\mathrm{b}}$ & $6.96^{\mathrm{a}}$ & $2.60^{\mathrm{ab}}$ & 0.137 \\
Acetate & $3.03^{\mathrm{a}}$ & $2.09^{\mathrm{b}}$ & $0.56^{\mathrm{ab}}$ & $0.58^{\mathrm{ab}}$ & 0.033 \\
Propionate & $0.65^{\mathrm{a}}$ & $0.50^{\mathrm{b}}$ & $2.59^{\mathrm{a}}$ & $2.39^{\mathrm{a}}$ & 0.074 \\
Lactate/acetate ratio & $1.05^{\mathrm{c}}$ & $1.97^{\mathrm{b}}$ & $208.9^{\mathrm{a}}$ & $203.9^{\mathrm{a}}$ & 8.040 \\
Aerobic stability, h & $202.7^{\mathrm{a}}$ & $168.0^{\mathrm{b}}$ & 7.00 & 6.97 & 0.141 \\
LAB (log10 cfu/g) & 7.32 & 7.00 & $6.01^{\mathrm{b}}$ & $6.06^{\mathrm{b}}$ & 0.125 \\
Yeast (log10 cfu/g) & $6.57^{\mathrm{a}}$ & $6.01^{\mathrm{b}}$ & 3.72 & 3.72 & 0.169 \\
Mold (log10 cfu/g) & 4.02 & 3.72 & &
\end{tabular}

SEM, standard error of the mean.

$\mathrm{CON}$, distilled water at $2 \mathrm{~mL} / \mathrm{kg}$ of forage; INO, Lactobacillus plantarum at $1.5 \times 10^{7} \mathrm{cfu} / \mathrm{g}$ of fresh forage; PRO, propionic acid at $1 \mathrm{~g} / \mathrm{kg}$ of forage; MIX, mixture of INO and PRO at 1:1 ratio.

${ }^{a, b, c}$ Means in the same row with different superscripts differ significantly $(\mathrm{p}<0.05)$.

silage compared to CON silage. Highest lactate to acetate ratio were observed in PRO and MIX silages followed by INO and CON silages $(p<0.05)$. The aerobic stability (hour) in CON, PRO, and MIX silages were significantly higher $(p<0.05)$ than in INO silage. The LAB and mold count were not affected by treatments $(\mathrm{p}>0.05)$. However, yeast count was significantly reduced $(\mathrm{p}<0.05)$ by all treatments compared to the control, but there was no difference among treated silages. The result of gel electrophoresis after PCR amplification of $L$. plantarum DNA in silages is expressed in Figure 1. Presence of $L$. plantarum DNA was detected only in L. plantarum inoculated silage (INO), but not in other silages.

\section{DISCUSSION}

\section{Chemical composition of fresh forage and silage}

The chemical composition of barley forage (Youngyang) was similar to the findings of Amanullah et al.
(2014) except for DM content, which was reported to be much higher $(47.9 \%)$ in their study than in the present (29.7\%). Unlike Amanullah et al. (2014), daylong wilting of forage was not practiced in the present study. Earlier, 30.7\% of DM content of un-wilted barley forage harvested at mid-

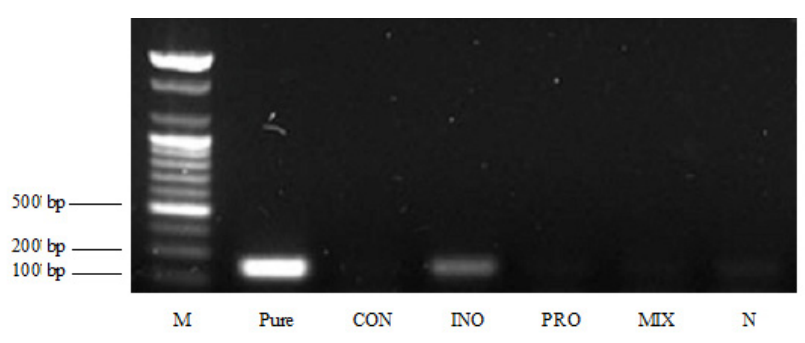

Figure 1. Gel electrophoresis analysis after polymerase chain reaction amplification of DNA from barley silage (Youngyang) fermented for 100 days. M, marker; Pure, pure culture of Lactobacillus plantarum; CON, no additive; INO, L. plantarum; PRO, propionate, MIX, mixture of INO and PRO; NTC, negative control. 
dough stage was reported by Hristov and McAllister (2002). Variation in forage chemical composition could occur commonly as it depends on varietal difference, soil composition, application of fertilizer and maturity at harvest (Adesogan et al., 2002).

As observed in this study, and also reported in some other studies (Zahiroddini et al., 2004; Zahiroddini et al., 2006; Baah et al., 2011), silage DM content was unaffected by bacterial inoculation or application of other additives. The decreased $\mathrm{CP}$ content along with higher $\mathrm{NH}_{3}-\mathrm{N}$ concentration in INO silage indicated higher protein decomposition in this treatment. Usually, the use of $L$. plantarum is considered to be advantageous over the indigenous bacteria or the heterofermentative $\mathrm{LAB}$ due to its ability to produce a rapid drop in $\mathrm{pH}$, and silage with low $\mathrm{NH}_{3}-\mathrm{N}$ (McDonald et al., 1991). In our previous study (Amanullah et al., 2014), we observed higher protein loss in $L$. plantarum inoculated silages. Possibly, the strain of $L$. plantarum that we used in present and in the previous studies has some sort of antagonism or absence of synergism with the naturally occurring epiphytic bacteria of this particular barley variety (Youngyang). Ohyama et al. (1971) found that in some cases, L. plantarum inoculation failed to produce desirable quality of silage compared with the well preserved control silage. The presence of such antagonism or absence of synergism, especially in terms of proteolysis, requires confirmation in a future study. The reduction of EE in PRO silage is difficult to explain with the current evidence available regarding propionic acid effects on silage fat content. The effect of L. plantarum or propionic acid on silage fiber concentration is inconsistent. In present study, the $\mathrm{ADF}$ concentration was significantly reduced by all treatments. Similar to the present findings, Kung and Ranjit (2001) reported a reduced ADF concentration in the treatments having a blend of homolactic bacteria including $L$. plantarum and buffered propionic acid. On the other hand, Mills and Kung (2002) reported $\mathrm{ADF}$ concentration was unaffected by buffered propionic acid based inoculant compared to the control. The lowest IVDMD in CON silage could be supported partially with higher ADF and lower lactate contents.

\section{Fermentation characteristics and aerobic stability}

As expected, the final $\mathrm{pH}$ of INO, PRO, and MIX silage reduced significantly compared to the $\mathrm{CON}$ silage. The homofermentative LAB inoculants are efficient at improving forage conservation by increased production of lactic acid and thereby reducing $\mathrm{pH}$ rapidly (Henderson, 1993; Muck, 1993). Lower terminal $\mathrm{pH}$ in barley silage by blended inoculants of homolactic bacteria including $L$. plantarum and buffered propionic acid was reported by Kung and Ranjit (2001). Unlike in other treatments, the lower $\mathrm{pH}$ in L. plantarum inoculated silage (INO) failed to preserve silage protein efficiently compared to others as evidenced by lowest $\mathrm{CP}$ and highest $\mathrm{NH}_{3}-\mathrm{N}$ concentration in this silage. The INO silage also had the lowest lactate concentration along with the CON silage, while it was supposed to have higher lactate in silages inoculated with homolactic L. plantarum (Henderson, 1993). In the present study, significantly higher (almost double) lactic acid was observed in PRO and MIX silage. It may happen that propionic acid results in rapid acidification (Table 2) of the crops which inhibits the growth of aerobic microorganisms (Woolford, 1984) at the very early stages (2 to 7 days) and therefore allowed the LAB to use a maximum portion of substrate to produce higher amounts of lactic acid. Theoretically, propionic acid should be higher in silages where it was added (PRO and MIX). Nevertheless, the propionic acid content was higher in these two treatments at early stages of fermentation ( 2 to 7 days), which, however, did not persist to the end (Table 4). The reduced yeast and mold (numerically) count and increased aerobic stability in PRO and MIX silage were therefore due to their higher propionic acid concentration, especially at early stage of ensiling. The inhibitory effect of propionic acid on yeast in silage was reported earlier (Weinberg and Muck, 1996). Substantial improvement in silage aerobic stability treated with propionic acid based additives was also reported (Kung et al., 1998; Kung et al., 2000). Though, CON silage has the highest terminal propionic acid concentration, the highest $\mathrm{pH}$ in this silage might limit the inhibiting effect of propionic acid on yeast and mold growth. It was reported that the antimycotic effect of propionic acid is enhanced as $\mathrm{pH}$ declines (Woolford, 1975). Nevertheless, the CON silage somehow achieved considerable aerobic stability along with PRO and MIX even with a numerically higher yeast and mold count. This silage was only 6 hours less stable than PRO silage upon aerobic exposure. The DNA band mass of L. plantarum in gel electrophoresis study indicated the persistence of inoculated L. plantarum and domination of fermentation in INO silage (Figure 1). Fermentation in CON, PRO, and MIX silages might be dominated by LAB bacteria other than L. plantarum.

\section{CONFLICT OF INTEREST}

We certify that there is no conflict of interest with any financial organization regarding the material discussed in the manuscript.

\section{ACKNOWLEDGMENTS}

This work was carried out with the support of 'Cooperative Research Program for Agriculture Science \& Technology Development' (Project No. PJ0097752015) by Rural Development Administration, Republic of Korea. 
And the authors (Dong Hyeon Kim, Sardar M. Amanullah, and Hyuk Jun Lee) were supported by a scholarship from the BK21 Plus Program, the Ministry of Education (Republic of Korea).

\section{REFERENCES}

Adesogan, A. T., L. E. Sollenberger, Y. C. Newman, and J. M. B. Vendramin. 2002. Factors affecting forage quality. In: Florida Forage Handbook (Ed. Y. C. Newman). University of Florida IFAS Exension, Gainesville, FL, USA. pp. 179-183.

Adesogan, A. T., N. Krueger, M. B. Salawu, D. B. Dean, and C. R. Staples. 2004. The influence of treatment with dual purpose bacterial inoculants or soluble carbohydrates on the fermentation and aerobic stability of bermudagrass. J. Dairy Sci. 87:3407-3416.

Amanullah, S. M., D. H. Kim, H. J. Lee, Y. H. Joo, S. B. Kim, and S. C. Kim. 2014. Effects of microbial additives on chemical composition and fermentation characteristics of barley silage. Asian Australas. J. Anim. Sci. 27:511-517.

AOAC. 1995. Official Methods of Aanalysis. 15th edn, Association of Official Analytical Chemists, Arlington, VA, USA.

Baah, J., W. Addah, E. K. Okine, and T. A. McAllister. 2011. Effects of homolactic bacterial inoculant alone or combined with an anionic surfactant on fermentation, aerobic stability and in situ ruminal degradability of barley silage. Asian Australas. J. Anim. Sci. 24:369-378.

Bolsen, K. K., D. R. Bonilla, G. L. Huck, M. A. Young, and R. A. Hart-Thakur. 1996. Effect of a propionic acid bacterial inoculant on fermentation and aerobic stability of whole-plant corn silage. Kansas Agric. Exp. Stn. Res. Rep. 756:77-88.

Chaney, A. L. and E. P. Marbach. 1962. Modified reagents for determination of urea and ammonia. Clin. Chem. 8:130-132.

Cleale R. M. IV, J. L. Firkins, F. Van Der Beek, J. H. Clark, E. H. Jaster, G. C. McCoy, and T. H. Klusmeyer. 1990. Effect of inoculation of whole plant corn forage with Pediococcus acidilactici and Lactobacillus xylosus on preservation of silage and heifer growth. J. Dairy Sci. 73:711-718.

Courtin, M. G. and S. F. Spoelstra. 1990. A simulation model of the microbiological and chemical changes accompanying the initial stage of aerobic deterioration of silage. Grass Forage Sci. 45:153-165.

Driehuis. F., S. J. W. H. Oude Elferink, and P. G. Van Wikselaar. 2001. Fermentation characteristics and aerobic stability of grass silage inoculated with Lactobacillus buchneri, with or without homofermentative lactic acid bacteria. Grass Forage Sci. 56:330-343.

Filya I. and E. Sucu. 2007. The effect of bacterial inoculants and a chemical preservative on the fermentation and aerobic stability of whole-crop cereal silages. Asian Australas. J. Anim. Sci. 20:378-384.

Hargreaves, A., J. Hill, and J. D. Leaver. 2009. Effect of stage of growth on the chemical composition, nutritive value and ensilability of whole-crop barley. Anim. Feed Sci. Technol. 152:50-61.

Henderson, N. 1993. Silage additives. Anim. Feed Sci. Technol. 45:35-56.
Higginbotham G. E., S. C. Mueller, K. K. Bolsen, and E. J. DePeters. 1998. Effects of inoculants containing propionic acid bacteria on fermentation and aerobic stability of corn silage. J. Dairy Sci. 81:2185-2192.

Hristov, A. N. and T. A. McAllister. 2002. Effect of inoculants on whole-crop barley silage fermentation and dry matter disappearance in situ. J. Anim. Sci. 80:510-516.

Kung, L., Jr. and N. K. Ranjit. 2001. The effect of Lactobacillus buchneri and other additives on the fermentation and aerobic stability of barley silage. J. Dairy Sci. 84:1149-1155.

Kung, L., Jr., J. R. Robinson, N. K. Ranjit, J. H. Chen, C. M. Golt, and J. D. Pesek. 2000. Microbial populations, fermentation end-products, and aerobic stability of corn silage treated with ammonia or a propionic acid-based preservative. J. Dairy Sci. 83:1479-1486.

Kung, L., Jr., A. C. Sheperd, A. M. Smagala, K. M. Endres, C. A. Bessett, N. K. Ranjit, and J. L. Glancey. 1998. The effect of preservatives based on propionic acid on the fermentation and aerobic stability of corn silage and a total mixed ration. J. Dairy Sci. 81:1322-1330.

Lindgren, S., K. Petterson, A. Kaspersson, A. Jonsson, and P. Lingvall. 1985. Microbial dynamics during aerobic deterioration of silages. J. Sci. Food Agric. 36:765-774.

McDonald, P., A. R. Henderson, and S. J. E. Heron. 1991. The Biochemistry of Silage. 2nd edn. Chalcombe Publications, Bucks, England.

Mills, J. A. and L. Kung, Jr. 2002. The effect of delayed ensiling and application of a propionic acid-based additive on the fermentation of barley silage. J. Dairy Sci. 85:1969-1975.

Muck, R. E. 1993. The role of silage additives in making high quality silage. In: Silage Production: from Seed to Animal. Proceedings from the National Silage Production Conference, Syracuse, NY, USA. pp. 46-47.

Muck, R. E. 2004. Effects of corn silage inoculants on aerobic stability. Trans. ASAE. 47:1011-1016.

Muck, R. E. and L. Kung, Jr. 1997. Effects of silage additives on ensiling. In: Silage: Field to Feedbunk. NRAES-99. Northeast Regional Agricultural Engineering Service, Ithaca, NY, USA. pp. 187-199.

Ohyama, Y., S. Masaki, A. Takigawa, and T. Morichi. 1971. Studies on various factors affecting silage fermentation IX: Synergistic effect of inoculation of lactobacillus plantarum and addition of glucose on silage quality. Jap. J. Zootech. Sci. 42:1-8.

Pitt, R. E., Y. Liu, and R. E. Muck. 1991. Simulation of the effect of additives on aerobic stability of alfalfa and corn silages. Trans. ASAE. 34:1633-1641.

Ranjit, N. K. and L. Kung, Jr. 2000. The effect of Lactobacillus buchneri, Lactobacillus plantarum, or a chemical preservative on the fermentation and aerobic stability of corn silage. J. Dairy Sci. 83:526-535.

SAS Institute Inc. (2002). SAS/STAT User's Guide (Version 9). Cary, NC, USA.

Sucu, E. and I. Filya. 2006. Effects of bacterial inoculants on fermentation, aerobic stability and rumen degradability characteristics of wheat silages. Turkish J. Vet. Anim. Sci. 30:187-193.

Tilley, J. M. A. and R. A. Terry. 1963. A two-stage technique for the in vitro digestion of forage crops. Grass Forage Sci. 
18:104-111

Van Soest, P. J., J. B. Robertson, and B. A. Lewis. 1991. Methods for dietary fiber, neutral detergent fiber, and nonstarch polysaccharides in relation to animal nutrition. J. Dairy Sci. 74:3583-3597.

Weinberg, Z. G. and R. E. Muck. 1996. New trends and opportunities in the development and use of inoculants for silage. FEMS Microbiol. Rev. 19:53-68.

Woolford, M. K. 1975. Microbiological screening of the straight chain fatty acids (C1-C12) as potential silage additives. J. Sci. Food Agric. 26:219-228.
Woolford, M. K. 1984. The Silage Fermentation. Marcel Dekker, Inc., New York, NY, USA.

Zahiroddini, H., J. Baah, W. Absalom, and T. A. McAllister. 2004. Effect of an inoculant and hydrolytic enzymes on fermentation and nutritive value of whole crop barley silage. Anim. Feed Sci. Technol. 117:317-330.

Zahiroddini, H., J. Baah, and T. A. McAllister. 2006. Effects of microbial inoculants on the fermentation, nutrient retention, and aerobic stability of barley silage. Asian Australas. J. Anim. Sci. 19:1429-1436. 